\title{
Evaluation of Metabolizable Energy of Common Poultry Feed Ingredients Using the Pekin Duck as an Experimental Animal
}

A. Anwar, H. El-Alaily, H.S. Soliman, M.El-Zeiny and Karima S. Mohamed

Animal Production Dept., Faculty of Agriculture, Ain-Shams Univ., Shoubra El-Kheima Cairo, Egypt.

\begin{abstract}
CORRECTED ME was determined using Pekin ducks as experiumental animals and the values obtained were used in the formulation of their starting rations up to 8 weeks of age. The results obtained proved that the ME values were higher when ducks were used, and that the minimum ME requirements in their starting rations are $2900 \mathrm{~K} \mathrm{Cal} / \mathrm{kg}$ feed. The use of excess energy in rations having the same protein level $(16 \%)$ caused increase in the carcass fat and decrease of its protein. Other carcass characteristics, however, did not seem to be affected by using a ME range between 2900 and $3050 \mathrm{~K}$. Cal $/ \mathrm{kg}$ feed.

The increase in ME values was not related to an increase in the utilization of fibers alone but to all foeding compounds.
\end{abstract}

In common practice, the metabolizable energy values (ME) for ingredients used in poultry rations are generally measured with chicken as experimental animals (Hill and Anderson, 1958). The tendency of ducks however to deposit fat in their carcass is widely observed due to better energy utilization of the ingredients fed (Das et al, 1965).

There are also some unsolved problems associated with ME determination concerning differences some time detected between species (Slinger $e t a l$, 1964, Fisher and Shanonn 1973; Leeson et al 1974, and Sugden, 1974). Moreover, Das et al, (1965) reported differences in growth rate, body composition and in starvation heat production between ducks and chicks.

This work therefore, was designed to measure the ME values of some ingredients using the pekin duck as an experimental animal and the formulation of its rations according to these values.

\section{Experiment al}

Two experiments were carried out: the first included 160 day-old unsexed Pekin ducklings which were fed the control ration (Table 1) up to two weeks of age. The birds were distributed at random into 8 groups up to 4 weeks of age when each group was divided into two duplicates of 10 birds each. 
The eight diets (Table 1) consisted of the reference diet and another 7 test dicts were fed each to a different group( 2 duplicate) for 2 weeks. The ingredients tested were corn, wheat, barley and wheat bran and which substituted $40 \%$ glucose in diets $2,3,4$ and 5 . Fish meal, cottonseed meal and field bean, however substituted only $30 \%$ glucose in diet 6,7 and 8 (Table 1). ME/g feedstuff

$=\mathrm{ME} / \mathrm{g} \cdot$ glucose- $\frac{\mathrm{ME} / \mathrm{g} \cdot \mathrm{glucose} \text { diet-ME/g.test diet }}{\% \text { of test feedstuff in the diet }}$ (Hill : nd Anderson 1958)

The birds of the second experiment totalled 120day-old allotted into 4 groups with 2 duplicates of 15 birds each 4 experimental diets(Table 2) were fed in this experimental each for a difierent group (2 duplicates) from hatching up to 8 weeks of age when the parameters tested were calculated. The 4 diets contained the same $16 \%$ total protein level but each with a different ME leve!: 2600, 2750 2900 and $3050 \pm 25 \mathrm{~K} . \mathrm{Cal} / \mathrm{Kg}$ as calculated from the values obtained from the first experiment (diets $1 \mathrm{~m}, 2 \mathrm{~m}, 3 \mathrm{~m} \& 4 \mathrm{~m}$ ). The feed and water were supplied ad $l i b$ during the whole experimental period.

At the age of 8 weeks 4 ducks were chosen from each group to study the carcass characteristics and composition.

Analytical data for feed, excreta and meat were obtained using the methods described in the A.O.A.C. (1960). The analyses of variance (Snedecor, 1967), and differences between means were determined by Duncans (1955), the multiple range and multiple "F" test were used for any statistical significance.

\section{Results and Discussion}

The nitrogen corrected $M E_{\mathrm{N}}$ (Table 3 ) for corn, wheat, barley and wheat bran were $3521,3413,3318$ and $1681 \mathrm{KCal} / \mathrm{Kg}$. material, respectively. These values are in all cases significantly higher than those reported for chicken (NRC, 1977 ) and which are commonly for the formulation of both chicks and ducks. The same trend of results was obtained for the protein concentrates tested except for fish meal which was only $1471 \mathrm{KCal} / \mathrm{kg}$, while that for cottonseed meal and field beans were 2377 and $2394 \mathrm{KCal} / \mathrm{kg}$. (Table 3). Those results are in agreement with those reported by Farrell (1981) who found that food and ME were significantly higher for pikin ducklings than for chicken. He also detected higher heat and energy production accompained by fat and protein retention in ducklings than chicken. Ducks whether Muscovy or Pekin were reported by Schubert et al (1982) to give better digestibility coefficient for organic matter, crude fiber, $\mathrm{N}$-free extract and crude protein than the laying hen. It seems that he increase in ME values was not related to an increase in the fiber utilization alone. In the second experiment different calorie: protein ratio was used and calculated with the help of ME values as calculated from the chicken and as determined on the pekin duck. The results given in Table 4.

Egypt. J. Anim. Prod. 25, No. 1 (1985) 
EVALUATION OF METABOLIZABLE ENERGY OF GOMMON.

TABLE 1. Composition of diets used for first experiment. Reference and experimental diets.

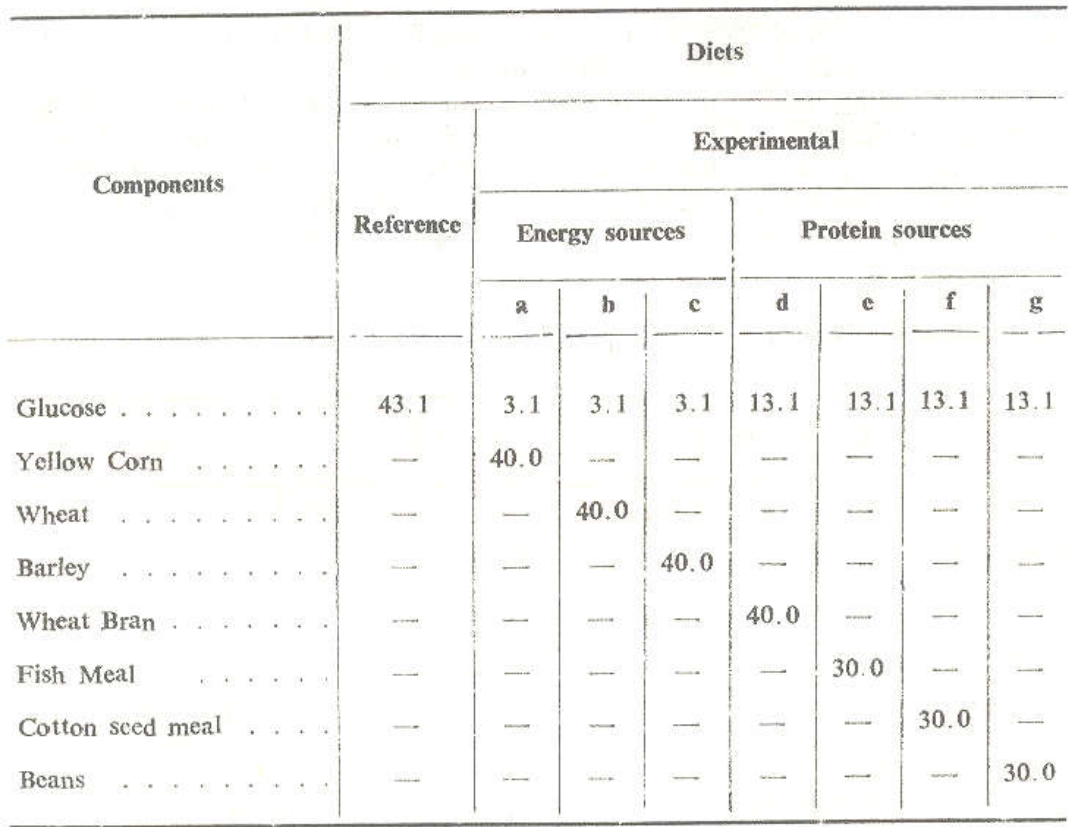

The rest of the $100 \%$ was fulfilled by $9 \%$ wheat bran, $17.5 \%$ cotton seed meal, $10.5 \%$ crude casin, $2.5 \%$ gelatin, $2.5 \%$ hydrogenated vegetable fat, $2.5 \%$ yeast, $5.0 \%$ fish meal $2.0 \%$ dried whey, $2.0 \%$ ground lime stone, $1.0 \%$ dicalcium phosphate, $0.5 \%$ dried salt (iodized), $0.4 \%$ mineral mixture, $0.5 \%$ vitamin mixture and $1 \%$ ground rice containing $30 \% \mathrm{Cr}_{2} \mathrm{O}_{3}$.

show significant differences $(\mathrm{P}<0.01)$ at 8 weeks of age for average live weight gain, daily gain energy consumption, efficiency of feed utilization and that of energy as well.

It seems that the minimum ME requirements for pekin ducks are 2900 $\mathrm{KCal} / \mathrm{Kg}$. feed from hatching and up to 8 weeks of age as calculated on the duck itself (Table 4).

These results indicate that the differences in the averages of live weight, liv weight gains, daily gain and efficiency of feed utilization at 8 weeks of age were statistically significant between ducks given diets 4 or 3 and those given diets 2 or 1 .

Also it was clear that the differences between the ducks given diet 4 and those given diet 3 were not significant (Table 4).

Egypt. J. Anim. Prod. 25, No. 1 (1985) 
The data presented in Table 5 for carcass composition showed progressive increase in the fat content and progressive reduction in protein content parallel to the increase of feed energy. The ME value of $2600 \mathrm{KCl} / \mathrm{kg}$ caused the carcass to contain $20.20 \%$ fat and $15.15 \%$ total protein (diet 1 ) while the ME value of $3050 \mathrm{KCal} / \mathrm{kg}$, caused the same two parameters to be 32.05 and $13.32 \%$ : respectively (Table 5). These results indicate that the carcass fat mostly depend upon the energy to protein in the diet as reported by Scott et al. (1959). Carcass characteristics, however did not seem to be very much affected within the calorie: protein ratio tried out in this experiment ((Table 6).

T ABLE 2. Composition of diets for second experiment.

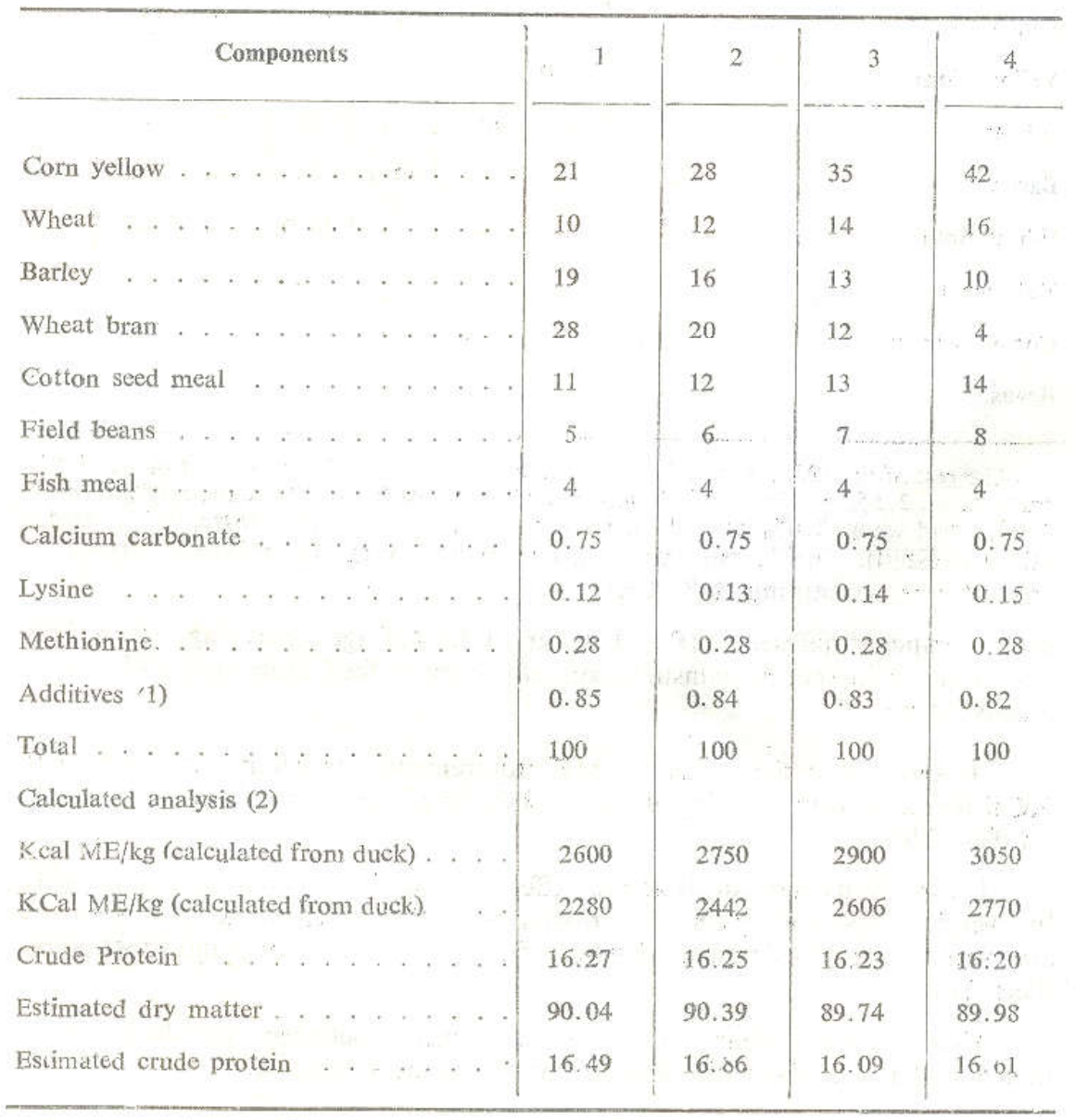

Egypt. J. Anim. Prod. 25, No. 1 (1985) 
EVALUATION OF METABOLIZABLE ENERGY OF GOMMON.

TABLE 3. Classical nitrogen corrected metabolizable energy values of some ingredients - measure.

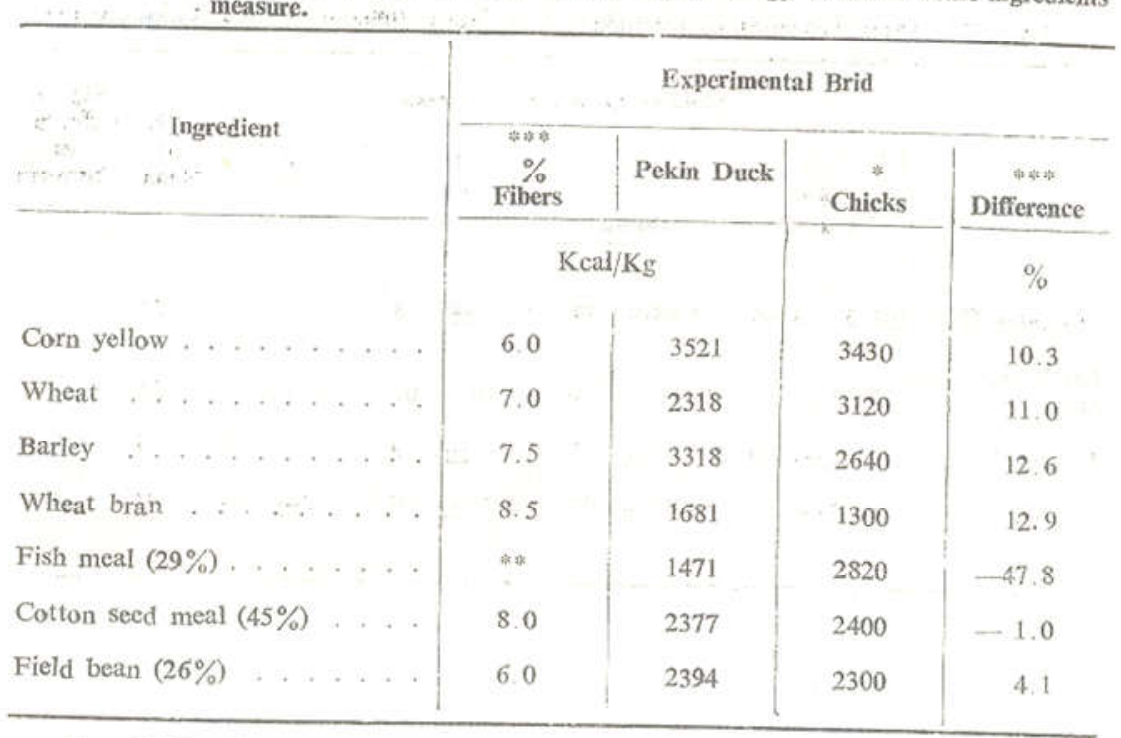

* NRC 1977

* The fish meal sample was a local product of very low quality.

*** The differences were not significant to fibre content alone.

TABLE 4: Msaz valuss with the SE for the perfomance of different groups at 8 weeks of age.

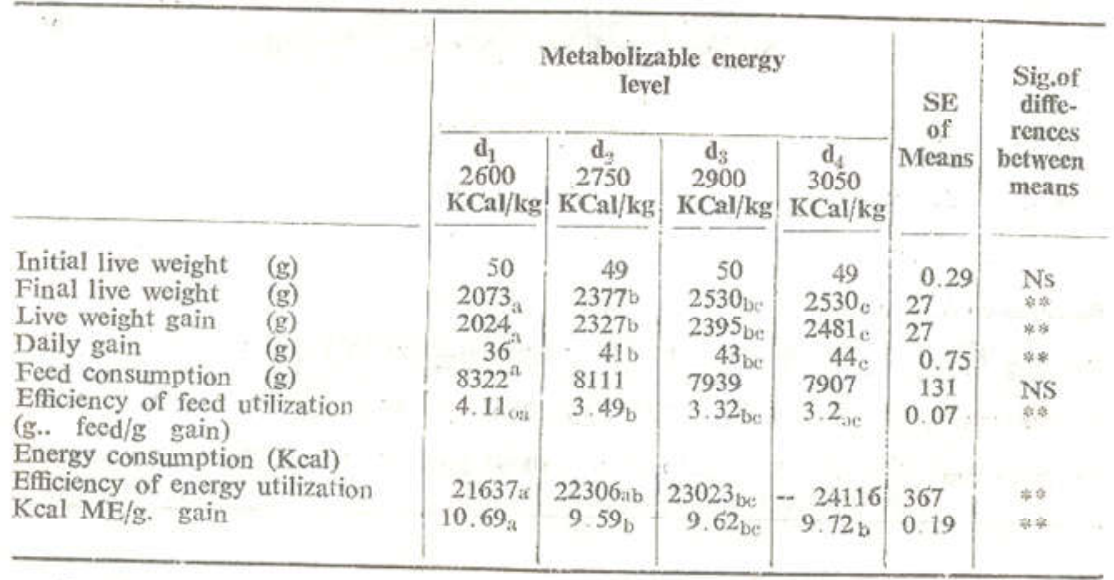

In this and subsequent tablets :-

* Significant at $5 \%$ level of probability.

Sgnificant at $1 \%$ level of probability.

SE standard error.

Figures followed by the same letter did not differ significantly (5 Duncans, 1955)

Egypl. J. Anim. Prod. 25, No. 1 (1985) 
TABLE 5. Average chemical composition of duck flesh at different groups at 8 weeks of age.

\begin{tabular}{|c|c|c|c|c|c|c|}
\hline & \multicolumn{4}{|c|}{ Metabolizable Energy Levels } & \multirow{2}{*}{$\begin{array}{c}\text { SE } \\
\text { of } \\
\text { Means }\end{array}$} & \multirow{2}{*}{$\begin{array}{c}\text { Sig. of } \\
\text { differenc- } \\
\text { es } \\
\text { between } \\
\text { means }\end{array}$} \\
\hline & $\begin{array}{c}\text { (1) } \\
2600 \\
\mathrm{Kcal} / \mathrm{kg}\end{array}$ & $\begin{array}{c}(2) \\
2750 \\
\text { Kcal/kg }\end{array}$ & $\begin{array}{c}(3) \\
2900 \\
\text { Kcal/kg }\end{array}$ & $\begin{array}{c}(4) \\
3050 \\
\mathrm{Kcal} / \mathrm{kg}\end{array}$ & & \\
\hline Moisture $\%$ & $63.87 \pm 3.66_{i 1}$ & $59.68 \pm 2.99 \mathrm{ab}$ & $55.07 \pm 2.18 b$ & $53.81 \pm 3.66 \mathrm{~b}$ & 1.84 & $*$ \\
\hline $\begin{array}{l}\text { Fat } \% \text { (other ext- } \\
\text { ract) }\end{array}$ & $20.20 \pm 1.50_{31}$ & $24.98 \pm 1.73 \mathrm{~b}$ & $30.10 \pm 2.01_{c}$ & $32.05 \pm 3.03 \mathrm{c})$ & 1.24 & $\approx *$ \\
\hline Protein $\%$. . & $15.15 \pm 2.10$ & $14.52 \pm 1.31$ & $14.07 \pm 0.19$ & $13.32 \pm 0.84$ & 0.76 & NS \\
\hline Ash $\% \ldots$ & $0.78 \pm 0.07$ & $0.82 \pm 0.07$ & $0.76 \pm 0.06$ & $0.82 \pm 0.04$ & 0.04 & NS \\
\hline
\end{tabular}

TABLE 6. Average carcass characteristics of different groups at 8 weeks of age.

\begin{tabular}{|c|c|c|c|c|c|c|}
\hline & \multicolumn{4}{|c|}{ Metabolizable Energy levels } & \multirow{2}{*}{$\begin{array}{c}\text { SE } \\
\text { of } \\
\text { Means }\end{array}$} & \multirow{2}{*}{$\begin{array}{l}\text { Sig.of } \\
\text { differ- } \\
\text { ences } \\
\text { between } \\
\text { means }\end{array}$} \\
\hline & $\begin{array}{c}(1) \\
2600 \\
\mathrm{Kcal} / \mathrm{kg}\end{array}$ & $\begin{array}{c}(2) \\
2750 \\
\text { Keal } / \mathrm{kg}\end{array}$ & $\begin{array}{c}(3) \\
2900 \\
\text { Keal/kg }\end{array}$ & $\begin{array}{c}(4) \\
3050 \\
\mathrm{Keal} / \mathrm{kg}\end{array}$ & & \\
\hline$\omega^{2}$ & & & & & & \\
\hline Live weight $(\mathrm{g}) \ldots$ & 2173 & 3110 & 2760 & 2787 & - & 一 \\
\hline Dressed weight $(\mathrm{g}) \ldots$ & 1903 & 2720 & 2403 & 2430 & - & - \\
\hline Eviscreated weight $(\mathrm{g})^{1}$ & 1275 & 1875 & 1642 & 1705 & 一 & - \\
\hline Ready to cook weight $(\mathrm{g})^{2}$ & 1462 & 2128 & 1955 & 1927 & - & - \\
\hline Dressing $\% \ldots, \ldots$ & $87.6 \pm 1.25$ & $87.4 \pm 2.02$ & $87.0 \pm 1.41$ & $87.1 \pm 0.83$ & 0.80 & NS \\
\hline Eviscreating $\% \ldots$ & $58.8 \pm 2.78$ & $60.2 \pm 2.52$ & $59.4 \pm 3.67$ & $60.9 \pm 2.61$ & 1.69 & NS \\
\hline Ready to cook $\% \ldots$ & $67.4 \pm 2.19$ & $68.4 \pm 1.91$ & $67.2 \pm 2.86$ & $68.9 \pm 1.69 \mid$ & 1.27 & NS \\
\hline
\end{tabular}

Egypt. J. Anim. Prod. 25, No. 1 (1985) 
A.O.A.C. (1960). Official Methods of Association of Analysis. Association of official Agriculture Chemists.

Das, L.N.; Mishra, D.B. and Biswal, G. (1965). Comparison anatomy of the domestic duct (Anas boscas) Indian Veterinary $J .42: 320$.

Duncan, D.B. (1955). Multiple range and multiple "F" test". Biomerrics. 11, 1.

Farrell, D.J. (1981). An assessment of quick bioassay for determining the true metabolizable energy of poultry feedstuffs. World's Poult. Sci. J. 37, 72.

Fisher, C. and Shannot, D.W. (1973). „Metabolizable energy determination using chicks and turkeys". Br. Poult. Sci. 14, 609.

Hill, F.W. and Anderson, D.L. (1958). Comparison of metabolizable energy and productive energy determination with growing chicks. J. of Nutr. $64,587$.

Leeson, S.; Boorman; K.N, Lewis, D. and Shrimpton, D.H. (1974). Metabolizable encrgy studies with turkey: Metabolizable energy of diets ingradients Br. Poult. Sci. 15, 183.

National, Research, Council (1977). Nutrients requirement of domestic animals. Biological energy interrelationships and glassary of energy terms. Publication 1411. National Academy of Science, National Research Council, Washington, D.C.

Schubert, R., Richter, G. and Growth, K. (1982). Comparative investigation of the digestion performances of Cairina, Peking ducks and Laying hens". Arch. Tierernahrung Bd. 32.H. 718 S. 531-537. Berlin.

Scott, M.L.; Hill, F.W., Parsons, E.H. and Bruckner, J.H. (1959). Studies on duct nutrition 7. Effect of dietary energy : Protein relationships upon growth, feed utilization and carcass composition in market ducklings. Poult. Sci. 38, 497.

Slinger, S.J., Sibbold, I.R. and Pepper, W.F. (1964). The relative abilities of two breeds of chickens and two varieties of turkeys to metabolize dietary energy and dietary nitrogene" Poult. Sci. 43, 329.

Snedecor, G.W. (1967). "Statistical methods" Iowa State College press Ames, Iowa. U.S.A.

Sudgen, L.G. (1974). Energy metabolizable by bantam chickens and blue-winged tcal. Poult. Sci. 53, 2227. 


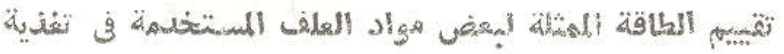

$$
\begin{aligned}
& \text { - }
\end{aligned}
$$

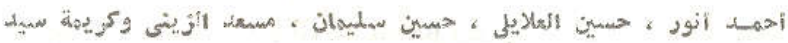

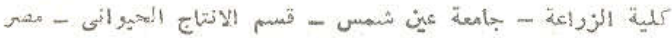

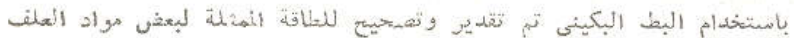

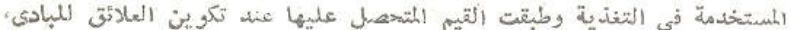

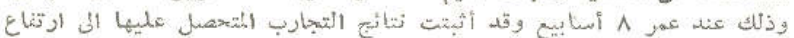

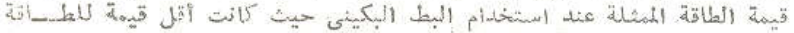

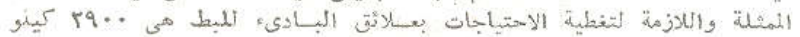

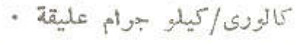

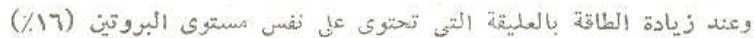

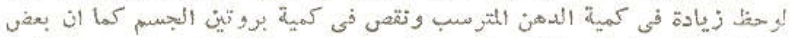

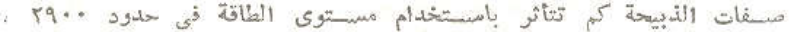

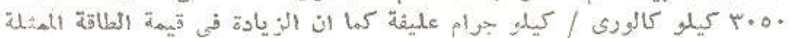

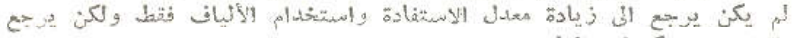

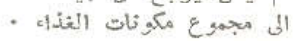

Ëgypt. J. Anim. Prod: 25, No. 1 (1985) 